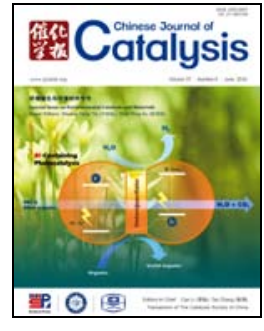

Article (Special Issue on Environmental Catalysis and Materials)

\title{
Ni-based catalysts derived from a metal-organic framework for selective oxidation of alkanes
}

\author{
Ying Zhou, Jilan Long *, Yingwei Li \# \\ State Key Laboratory of Pulp and Paper Engineering, School of Chemistry and Chemical Engineering, South China University of Technology, Guangzhou \\ 510640, Guangdong, China
}

A R T I C L E I N F 0

Article history:

Received 27 January 2016

Accepted 25 February 2016

Published 5 June 2016

\section{Keywords:}

Nickel

Nanoparticle

Metal-organic framework

Alkane

Oxidation

Heterogeneous catalysis

\begin{abstract}
A B S T R A C T
Ni nanoparticles embedded in nitrogen-doped carbon (Ni@C-N) materials were prepared by thermolysis of a Ni-containing metal-organic framework (Ni-MOF) under inert atmosphere. The as-synthesized $\mathrm{Ni@C-N} \mathrm{materials} \mathrm{were} \mathrm{characterized} \mathrm{by} \mathrm{powder} \mathrm{X-ray} \mathrm{diffraction,} \mathrm{N}_{2}$ adsorption-desorption analysis, scanning electron microscopy, transmission electron microscopy, atomic absorption spectroscopy, and X-ray photoelectron spectroscopy. The MOF-derived Ni-based materials were then examined as heterogeneous catalysts for the oxidation of alkanes under mild reaction conditions. The Ni@C-N composites displayed high activity and selectivity toward the oxidation of a variety of saturated $\mathrm{C}-\mathrm{H}$ bonds, affording the corresponding oxidation products in good-to-excellent yields. Furthermore, the catalysts could be recycled and reused for at least four times without any significant loss in activity and selectivity under the investigated conditions.
\end{abstract}

(C) 2016, Dalian Institute of Chemical Physics, Chinese Academy of Sciences. Published by Elsevier B.V. All rights reserved.

hexane oxidation needs careful control (at conversions of $<5 \%$ with $75 \%-80 \%$ selectivity to KA-oil) to prevent the production of excessive amounts of byproducts owing to over-oxidation [3-5].

Over the past few decades, considerable research efforts have been devoted to exploring efficient and environmentally sound methodologies for the selective oxidation of alkanes. In this regard, heterogeneous catalysis has received the most attention, and various efficient metal catalysts have been developed [6-23]. These catalysts include metal-incorporated molecular sieves [12], metal-substituted molecular sieves [13,15], supported $\mathrm{Au}$ nanoparticles [6,7,10,23], metal-organic frameworks (MOFs) [22], and carbon-based materials [24,25]. However, the development of cost-effective, and highly active and

\footnotetext{
* Corresponding author. Tel: +86-15182908656; E-mail: xlong612@126.com

\# Corresponding author. Tel: +86-20-87113656; E-mail: liyw@scut.edu.cn

This work was supported by the National Natural Science Foundation of China (21322606, 21436005, 21576095), the State Key Laboratory of Pulp and Paper Engineering (2015TS03), the Doctoral Fund of Ministry of Education of China (20120172110012), Fundamental Research Funds for the Central Universities (2015ZP002, 2015PT004), and Guangdong Natural Science Foundation (2013B090500027).
}

DOI: 10.1016/S1872-2067(15)61067-1 | http://www.sciencedirect.com/science/journal/18722067 | Chin. J. Catal., Vol. 37, No. 6, June 2016 
selective heterogeneous catalysts for the oxidation of alkanes remains a great challenge to date.

Of particular interest, MOFs are a well-known, new class of porous functional materials constituting metal ions and organic ligands. Owing to their ordered structures and relatively low thermal stability, MOFs have been used for the preparation of new metal oxides or carbon nanomaterials by thermal decomposition. As reported, MOF-derived materials exhibit excellent performance in various applications including heterogeneous catalysis [26-36], electrochemistry [37,38], and gas adsorption [39-41]. To our knowledge, reports on the use of MOF-derived materials as catalysts for liquid-phase organic synthesis are rare.

Herein, we report a novel, non-noble Ni-based heterogeneous catalytic system for the selective oxidation alkanes. Various alkanes, such as cyclohexane and ethylbenzene, could be selectively transformed into the desired aldehydes or ketones in high yields under mild conditions. The catalysts were prepared by simple thermolysis of a Ni-containing MOF under inert atmosphere.

\section{Experimental}

\subsection{Synthesis of Ni@C-N catalysis}

All chemicals were purchased from commercial corporations and used without further treatment.

Typically, a mixture of $\mathrm{Ni}(\mathrm{NO})_{3} \cdot 6 \mathrm{H}_{2} \mathrm{O} \quad(0.9 \mathrm{mmol})$, 1,4-benzenedicarboxylic acid ( $\mathrm{H}_{2}$ bdc; $\left.0.72 \mathrm{mmol}\right)$, triethylenediamine (dabco; $0.58 \mathrm{mmol}$ ), and dimethylformamide (DMF; 15 $\mathrm{mL}$ ) were added to a Teflon-lined autoclave. The reactor was heated in an oven at $120^{\circ} \mathrm{C}$ for $2 \mathrm{~d}$. The obtained green powder was then washed with DMF and methanol, and finally dried under vacuum at $150{ }^{\circ} \mathrm{C}$ for $2 \mathrm{~h}$.

The Ni@C-N catalysts were prepared by pyrolysis of Ni-MOF in an inert atmosphere. Ni-MOF was heated at a heating rate of $1{ }^{\circ} \mathrm{C} / \mathrm{min}$ from room temperature to $200{ }^{\circ} \mathrm{C}$ and maintained at this temperature for $2 \mathrm{~h}$ in Ar. Then, the temperature was increased to the target temperature (i.e., 500, 600, 700, 800, or $900^{\circ} \mathrm{C}$ ) at the same heating rate and subsequently maintained for 8 or $15 \mathrm{~h}$. The resulting samples were denoted as Ni@C-N- $x$-8h or Ni@C-N- $x-15 h$, where $x$ indicates the target thermolysis temperature $\left({ }^{\circ} \mathrm{C}\right)$.

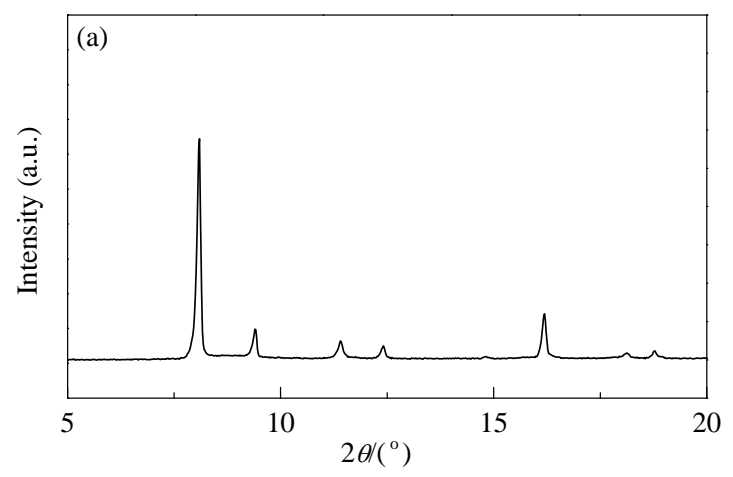

\subsection{Characterization}

Powder X-ray diffraction (PXRD) patterns of the prepared materials were recorded on a Rigaku diffractometer (D/MAX-IIIA; $3 \mathrm{~kW}$ ) using $\mathrm{Cu} K_{\alpha}$ radiation $(40 \mathrm{kV}, 30 \mathrm{~mA}, \lambda=$ $0.1543 \mathrm{~nm}$ ). $\mathrm{N}_{2}$ adsorption-desorption isotherms were measured on a Micromeritics ASAP 2020M instrument at $-196{ }^{\circ} \mathrm{C}$. The Ni content of the samples was determined quantitatively by atomic absorption spectroscopy (AAS) on a HITACHI Z-2300. The surface topography of Ni-MOF and the Ni@C-N materials was investigated by scanning electron microscopy (SEM; MERLIN of ZEISS). Transmission electron microscopy (TEM) images of the samples were recorded on a JEM-2010HR (JEOL) microscope. X-ray photoelectron spectroscopy (XPS) measurements were performed on a Kratos Axis Ultra DLD system with a base pressure of $1.33 \times 10^{-7} \mathrm{~Pa}$.

\subsection{Oxidation of alkanes over Ni@C-N}

The oxidation of alkanes (e.g., ethylbenzene) was conducted in a $25-\mathrm{mL}$ Schlenk tube. Typically, ethylbenzene $(0.5 \mathrm{mmol})$, catalyst (10 mol\% based on $\mathrm{Ni}$ ), tert-butyl hydroperoxide (TBHP; $1.5 \mathrm{mmol}$ ), and DMF ( $2 \mathrm{~mL}$ ) were added to the tube and heated at $80{ }^{\circ} \mathrm{C}$. After reaction, the catalyst was isolated from the mixture solution by centrifugation, then washed with DMF and methanol. The liquid mixtures were then analyzed by gas chromatography mass spectrometry (Agilent Technologies 7890B-5977A) on a chromatograph equipped with a $0.25 \mathrm{~mm}$ $\times 30$ m HP-5MS capillary column.

For the recyclability tests, the catalyst was separated from the reaction mixture and washed with DMF and methanol for several times. The solid was then dried at $80{ }^{\circ} \mathrm{C}$ in an oven and reduced by $\mathrm{H}_{2}$ at $200^{\circ} \mathrm{C}$ for $2 \mathrm{~h}$ before use for the next run.

\section{Results and discussion}

\subsection{Characterization of the materials}

Ni-MOF was prepared according to the procedures described in previous reports $[42,43]$. The PXRD pattern of the as-synthesized Ni-MOF (Fig. 1(a)) matched well with the published XRD patterns [42,43]. The $\mathrm{N}_{2}$ adsorption-desorption isotherm measured at $-196{ }^{\circ} \mathrm{C}$ indicated that Ni-MOF was

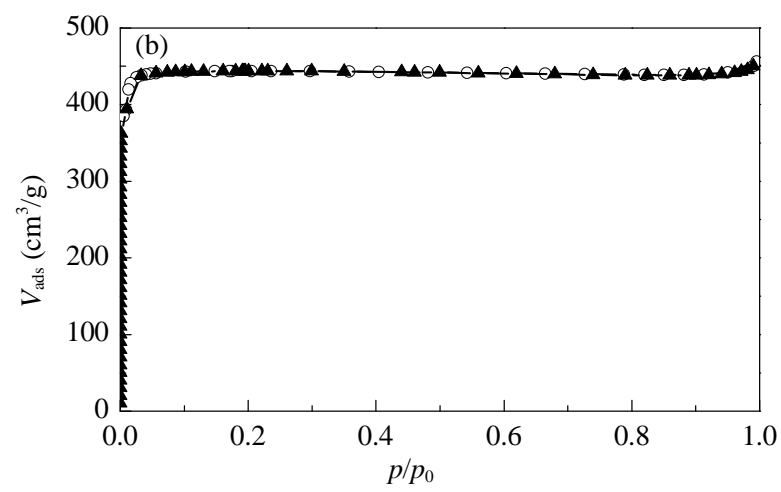

Fig. 1. (a) PXRD pattern and (b) $\mathrm{N}_{2}$ adsorption-desorption isotherm of as-synthesized Ni-MOF. 
mostly microporous (Fig. 1(b)). The Brunauer-Emmett-Teller (BET) surface area was calculated to be $\sim 1700 \mathrm{~m}^{2} / \mathrm{g}$.

The Ni@C-N materials were prepared by pyrolysis of Ni-MOF under a continuous flow of Ar for 8 or $15 \mathrm{~h}$ at varying temperatures. The $\mathrm{Ni}$ contents in the samples were $\sim 35-40$ wt\%. Fig. 2 shows the PXRD patterns of the Ni@C-N materials. All the prepared materials displayed five diffraction peaks at $\sim 44.4^{\circ}, 51.8^{\circ}, 76.4^{\circ}, 92.9^{\circ}$, and $98.5^{\circ}$, which are characteristics of metallic Ni (JCPDS No. 04-0850) [44]. The intensity of the Ni diffraction peaks increased with increasing pyrolysis temperatures employed, indicating the formation of $\mathrm{Ni}$ phase with a higher crystallization degree. The crystallite sizes of Ni Particles in the materials were in the range of 7-10 nm, as calculated by the Scherrer formula.

Fig. 3 shows the $\mathrm{N}_{2}$ adsorption-desorption isotherms of the $\mathrm{Ni@C-N} \mathrm{materials} \mathrm{measured} \mathrm{at}-196{ }^{\circ} \mathrm{C}$. All isotherms featured typical adsorption curves of types I and IV, with an apparent hysteresis loop in the relative pressure $\left(P / P_{0}\right)$ range of $0.5-1.0$, suggesting the presence of a micro-/meso-/macroporous structure in the Ni@C-N materials. The BET surface areas of the
$\mathrm{Ni@C-N} \mathrm{materials} \mathrm{were} \mathrm{calculated} \mathrm{to} \mathrm{be} \sim 100-200 \mathrm{~m}^{2} / \mathrm{g}$.

The surface morphology of the Ni@C-N materials was examined by SEM. The SEM images in Fig. 4(a)-(d) depict the initial shape of the Ni-MOF crystals when MOF was calcined below $700{ }^{\circ} \mathrm{C}$ for $8 \mathrm{~h}$. The surface of the materials became distorted and considerably rougher upon decomposition and carbonization of the MOF. When the pyrolysis temperature increased to $800{ }^{\circ} \mathrm{C}$, numerous nanotubes were obtained (Fig. $4(\mathrm{e})$ ), which might be catalyzed by the generated Ni nanoparticles.

The TEM images in Fig. 5 revealed that the metallic Ni nanoparticles were highly dispersed in the carbon matrix derived from carbonization of the organic linker in Ni-MOF. At the higher MOF pyrolysis temperatures, aggregation of the Ni nanoparticles into larger particles was observed. When the thermolysis temperature increased to $900{ }^{\circ} \mathrm{C}$, most of the particles agglomerated into large particles with an average size of $\sim 18$ nm (Fig. 6). High-resolution TEM analysis of an individual large particle indicated that each $\mathrm{Ni}$ nanoparticle was tightly embedded in the graphitic carbon (Fig. 6(c)).
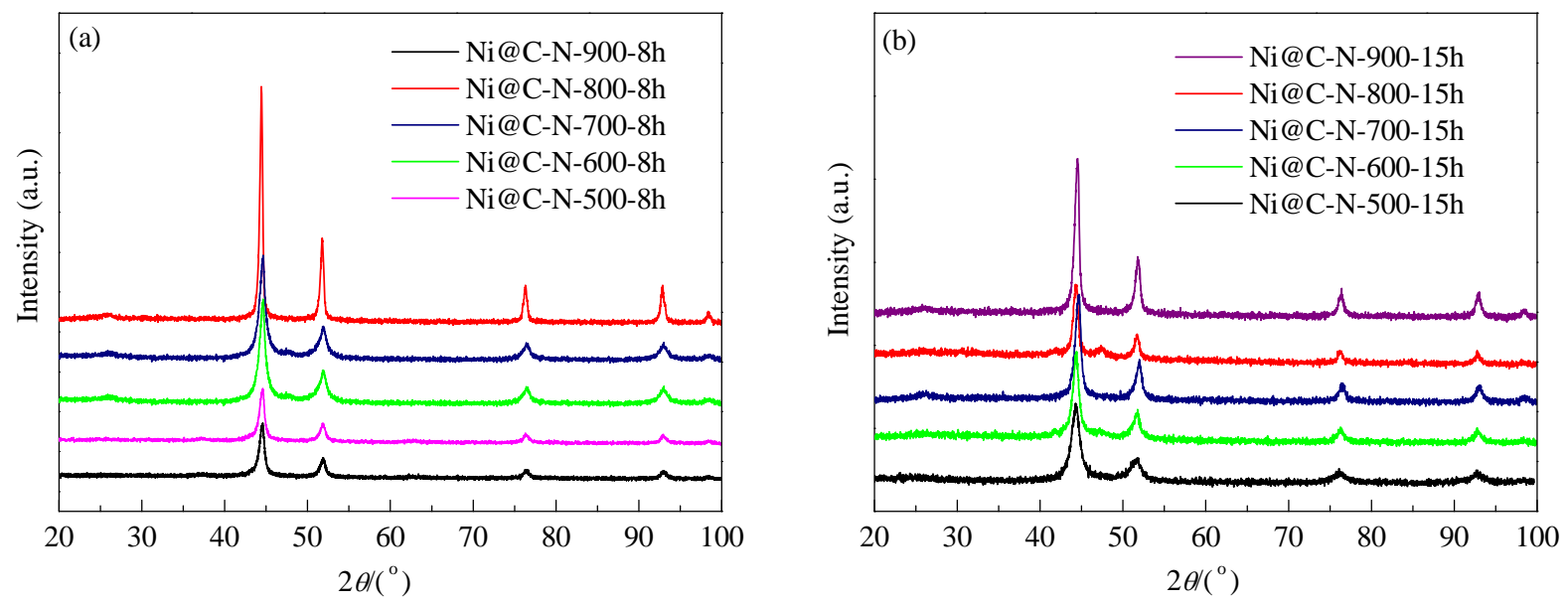

Fig. 2. PXRD patterns of (a) Ni@C-N-x-8h and (b) Ni@C-N- $x-15 h$.
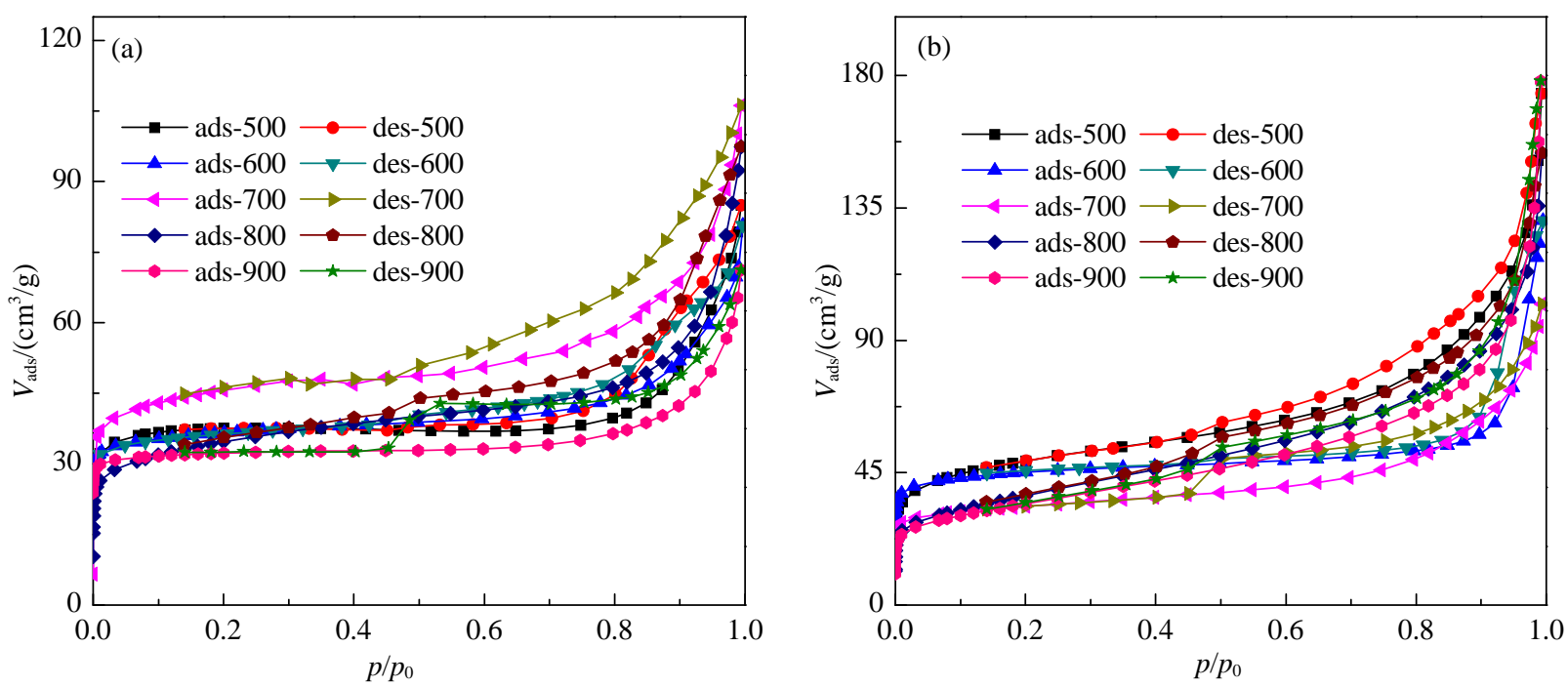

Fig. 3. $\mathrm{N}_{2}$ adsorption (ads)-desorption (des) isotherms of (a) Ni@C-N- $x-8 \mathrm{~h}$ and (b) Ni@C-N-x-15h. 

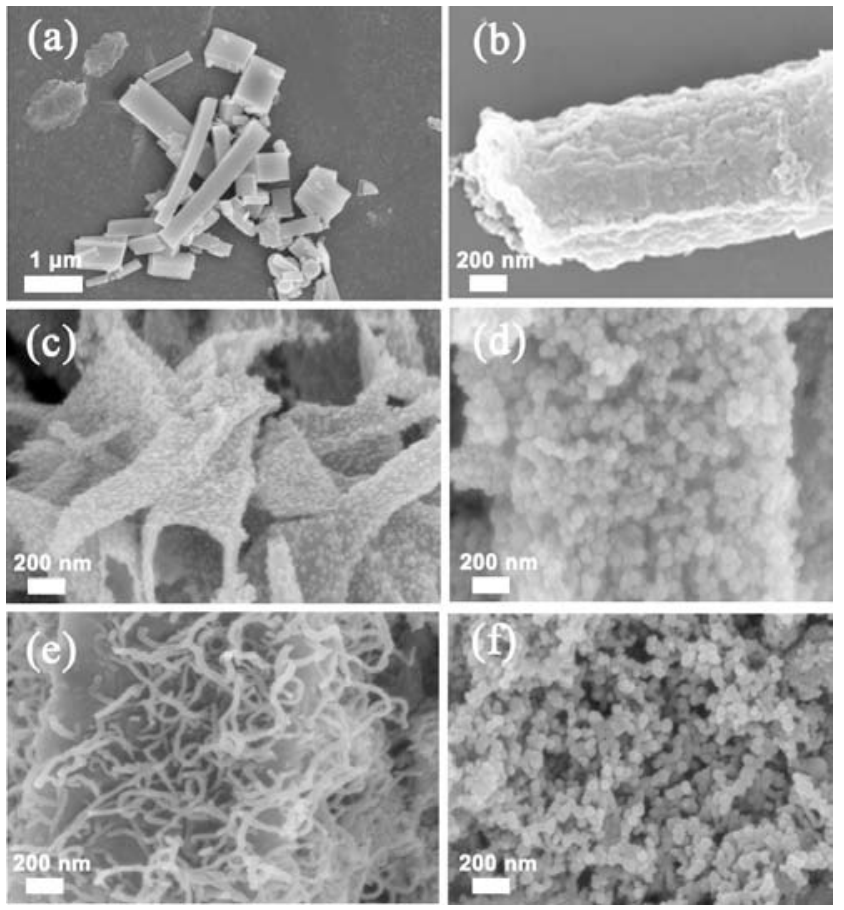

Fig. 4. SEM images of (a) Ni-MOF, (b) Ni@C-N-500-8h, (c) Ni@C-N-600-8h, (d) Ni@C-N-700-8h, (e) Ni@C-N-800-8h, and (f) Ni@C-N-900-8h.
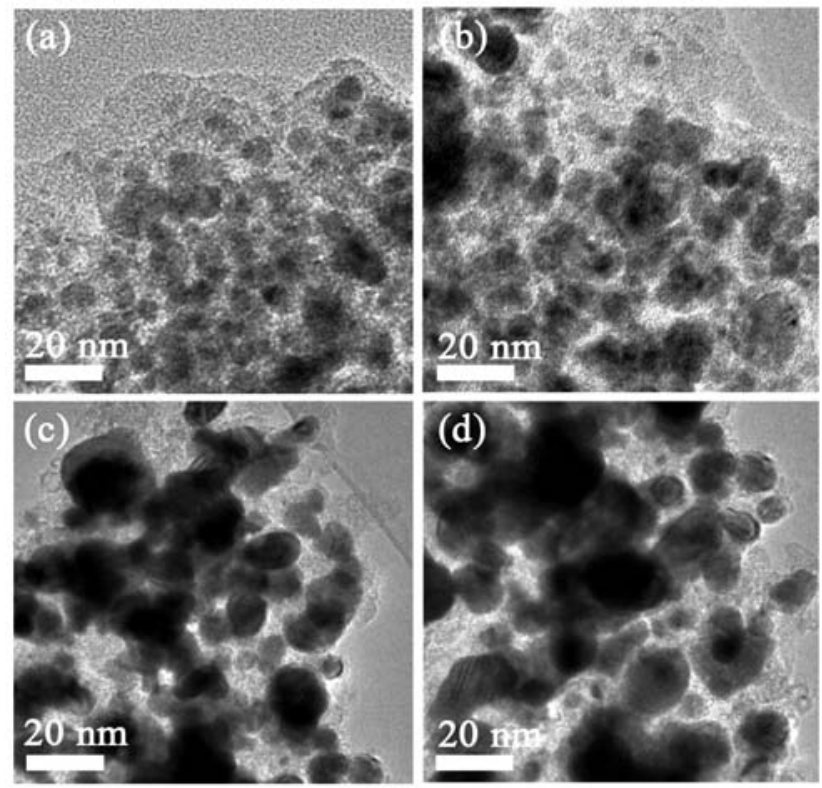

Fig. 5. TEM images of (a) Ni@C-N-500-8h, (b) Ni@C-N-600-8h, (c) Ni@C-N-700-8h, and (d) Ni@C-N-800-8h.

The XPS spectra of Ni-MOF and Ni@C-N-900-8h are shown in Fig. 7. The Ni $2 p$ peaks at 856.0 and $873.6 \mathrm{eV}$ could be assigned to $\mathrm{Ni}^{2+}$ in Ni-MOF (Fig. 7(a)). After thermolysis, the two Ni $2 p$ peaks of Ni@C-N-900-8h respectively shifted to lower binding energies by $\sim 3.2$ and $\sim 3.3 \mathrm{eV}$ relative to those of $\mathrm{Ni}-\mathrm{MOF}$, indicating that most of the Ni(II) ions in MOF were reduced to $\mathrm{Ni}(0)$ [45]. This result agreed with common experimental observations, whereby central metal ions of MOF with reduction potentials higher than $0.27 \mathrm{~V}$ are typically reduced to
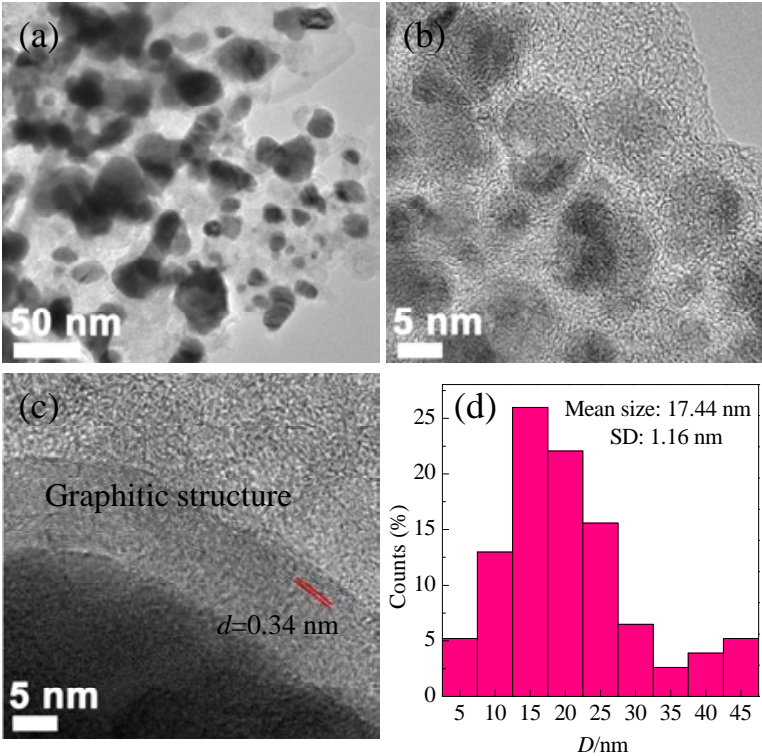

Fig. 6. (a, b) TEM images of Ni@C-N-900-8h. (c) High-resolution TEM image of a Ni particle and (d) corresponding size distribution of the $\mathrm{Ni}$ nanoparticles.

their metallic states upon calcination in an inert atmosphere [46-48]. The N $1 s$ peak of Ni-MOF appeared at $399.8 \mathrm{eV}$ and could be assigned to the $\mathrm{N}$ of triethylenediamine coordinated with a metal ion [49]. Interestingly, this bonding energy was slightly higher than that of amino nitrogen $(399.6 \mathrm{eV})$ owing to the influence of the magnetic metal center (i.e., $\mathrm{Ni}$ [ [50,51]. After thermolysis, the N $1 s$ spectra of Ni@C-N-900-8h showed two new peaks at 398.9 and $401.0 \mathrm{eV}$, which could be assigned to pyridinic $\mathrm{N}$ and graphitic $\mathrm{N}$, respectively [52]. This phenomenon was consistent with the TEM result (Fig. 6(c)) with respect to the formation of a graphitic structure.

\subsection{Catalytic oxidation of ethylbenzene over Ni@C-N}

First, ethylbenzene oxidation was employed as a model reaction to evaluate the catalytic activities of the as-synthesized $\mathrm{Ni@C-N} \mathrm{materials.} \mathrm{The} \mathrm{catalytic} \mathrm{reaction} \mathrm{was} \mathrm{conducted} \mathrm{at} 80$ ${ }^{\circ} \mathrm{C}$ using TBHP as oxidant, and the results are summarized in Table 1. The blank reaction, without any catalyst, achieved minimal conversion performance only (Table 1 , entry 1 ). In contrast, in the presence of the Ni@C-N materials, the oxidation transformation was efficiently promoted. The activity of the catalysts was strongly dependent on the pyrolysis temperature and time. Generally, the Ni@C-N materials prepared under higher MOF thermolysis temperatures showed higher activities (Table 1, entries 2-11), possibly because of the higher carbonization degree of the organic linkers in the MOF. In contrast, a longer pyrolysis time reduced the catalytic activity of the obtained Ni@C-N materials. Among the examined catalysts, $\mathrm{Ni} @ \mathrm{C}-\mathrm{N}-900-8 \mathrm{~h}$ displayed the best ethylbenzene oxidation performance (Table 1, entry 6), achieving an ethylbenzene-to-acetophenone conversion of $77 \%$ within $48 \mathrm{~h}$ of reaction at $80^{\circ} \mathrm{C}$. Moreover, a higher yield of acetophenone could be achieved by simply increasing the amount of TBHP, while 

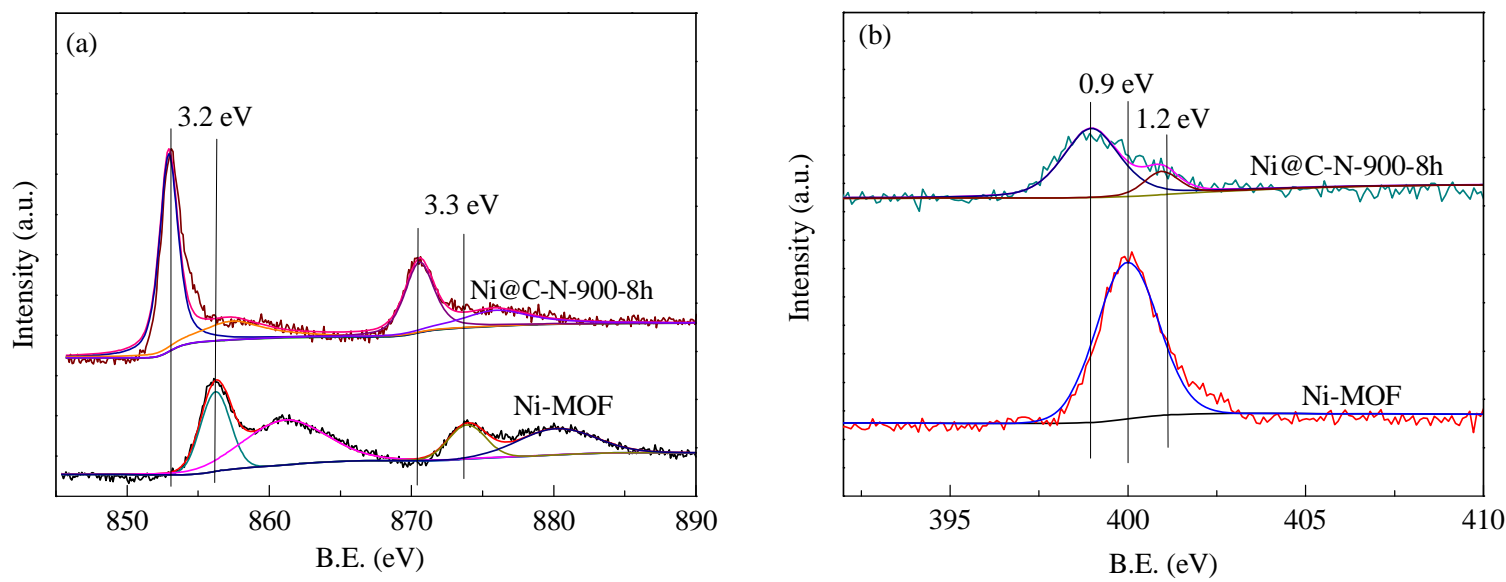

Fig. 7. (a) Ni $2 p$ and (b) N $1 s$ XPS spectra of Ni-MOF and Ni@C-N-900-8h.

maintaining other conditions constant (Table 1, entry 12).

Subsequently, the recyclability of Ni@C-N-900-8h catalyst toward ethylbenzene oxidation was examined. The results are presented in Table 1 (entries 6, 13-15); no significant decline in the conversion and selectivity performance was observed during repeated catalytic runs (up to four runs). These results demonstrate the high stability of the Ni@C-N catalyst under the investigated conditions.

\subsection{Oxidation of different alkanes over Ni@C-N}

To demonstrate the general applicability of the Ni@C-N catalysts, we extended the use of the present catalytic system (specifically, Ni@C-N-900-8h) to the oxidation transformations

Table 1

Results of the oxidation of ethylbenzene catalyzed by different Ni@C-N catalysts.

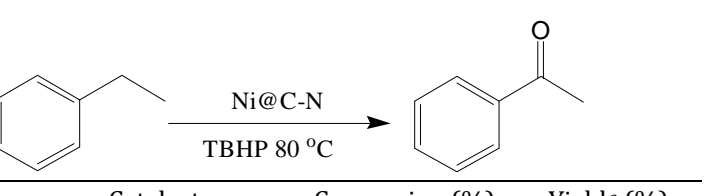

\begin{tabular}{lccc}
\hline Entry & Catalyst & Conversion (\%) & Yield $^{\mathrm{a}}(\%)$ \\
\hline 1 & Blank & 7 & 7 \\
2 & Ni@C-N-500-8h & 47 & 47 \\
3 & Ni@C-N-600-8h & 47 & 47 \\
4 & Ni@C-N-700-8h & 48 & 48 \\
5 & Ni@C-N-800-8h & 65 & 65 \\
6 & Ni@C-N-900-8h & 77 & 77 \\
7 & Ni@C-N-500-15h & 37 & 37 \\
8 & Ni@C-N-600-15h & 45 & 45 \\
9 & Ni@C-N-700-15h & 50 & 50 \\
10 & Ni@C-N-800-15h & 47 & 47 \\
11 & Ni@C-N-900-15h & 40 & 40 \\
$12^{\text {b }}$ & Ni@C-N-900-8h & $>99$ & $>99$ \\
$13^{\text {c }}$ & Ni@C-N-900-8h & 78 & 78 \\
$14^{\text {d }}$ & Ni@C-N-900-8h & 75 & 75 \\
$15^{\text {e }}$ & Ni@C-N-900-8h & 76 & 76 \\
\hline
\end{tabular}

a Reaction conditions: ethylbenzene $(0.5 \mathrm{mmol})$, catalyst (Ni $10 \mathrm{~mol} \%$ relative to ethylbenzene), DMF $(2 \mathrm{~mL})$, TBHP $(1.5 \mathrm{mmol}), 80^{\circ} \mathrm{C}, 48 \mathrm{~h}$. b TBHP 2.5 mmol. c Second run. d Third run. e Fourth run. of various saturated alkanes under similar reaction conditions. The results are summarized in Table 2. As observed, the various secondary $\mathrm{C}-\mathrm{H}$ bonds were oxidized smoothly with excel-

Table 2

Oxidation of various alkanes catalyzed by Ni@C-N-900-8h.

Entry Substrate $\quad T /{ }^{\circ} \mathrm{C} \quad t / \mathrm{h} \begin{gathered}\text { Conversion } \\ (\%)\end{gathered}$

4<smiles>CC1CCCC1</smiles>

100<smiles></smiles>

$>99$

5<smiles>C1CCCCC1</smiles>

100

48<smiles>CCc1cccc(Br)c1</smiles>

$80 \quad 50$

6<smiles>CCc1ccc(Br)cc1</smiles>

$80 \quad 50$<smiles>CCc1cccc(C)c1</smiles>

$80 \quad 20$

$>99$

9

58

$>99$

$>99$

8
3

18 80 >99<smiles>O=C1CC(=O)c2ccccc2C1=O</smiles><smiles>CC1CCC(=O)C1</smiles><smiles>O=C1CCC[GeH2]C1</smiles><smiles>CC(=O)c1cccc(Br)c1</smiles><smiles>CC(=O)c1ccc(Br)cc1</smiles>

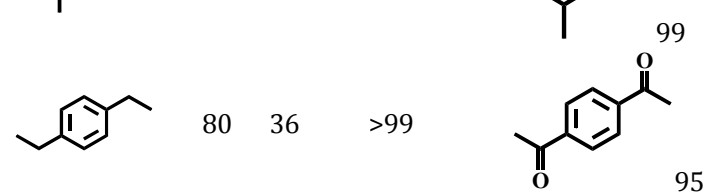

Reaction conditions: substrate $(0.5 \mathrm{mmol})$, catalyst (Ni $10 \mathrm{~mol} \%), \mathrm{DMF}$ (2 mL), TBHP (2.5 mmol). 
lent selectivities to their corresponding partial oxidation products (Table 2, entries 1-5). For the oxidation of cyclohexane, a moderate conversion with $100 \%$ selectivity to cyclohexanone was achieved at $100{ }^{\circ} \mathrm{C}$ (Table 2, entry 5). Substituted ethylbenzene containing either electron-withdrawing or electron-donating functional groups also displayed excellent conversions and selectivities to the corresponding ketones (Table 2 , entries 6-8). It was interesting to note that $\mathrm{Ni@C-N}$ was also highly active and selective toward the oxidation of 1,4-diethylbenzene, achieving $>95 \%$ selectivity to the diketone product (Table 3, entry 9). These results demonstrate the high versatility of the MOF-derived $\mathrm{Ni@C-N}$ catalysts prepared herein for the selective oxidation of alkanes.

\section{Conclusions}

We have developed novel, efficient, and cost-effective $\mathrm{Ni}$-based catalysts for application in the selective oxidation of alkanes. The Ni@C-N materials were prepared by direct thermolysis of a Ni-containing MOF under inert atmosphere. The as-prepared Ni nanoparticles embedded in the $\mathrm{C}-\mathrm{N}$ composites displayed high activity and selectivity in the oxidation of alkanes to their corresponding partial oxidation products under mild reaction conditions, thus showing a broad substrate scope for diverse saturated $\mathrm{C}-\mathrm{H}$ bonds. Moreover, the catalysts are highly stable and maintain high activity and selectivity during numerous repeated catalytic cycles under the investigated conditions. The present strategy may be extended to the development of other novel metal-carbon composite catalysts for selective catalytic oxidation applications.

\section{References}

[1] R. A. Sheldon, J. K. Kochi, Metal-Catalyzed Oxidations of Organic Compounds; Academic Press, New York, 1981, 26-33.

[2] U. Schuchardt, W. A. Calvarlho, E. V. Spinace, Synlett, 1993, 10, 713-718.

[3] K. Kamata, K. Yonehara, Y. Nakagawa, K. Uehara, N. Mizuno, Nat. Chem., 2010, 2, 478-483.

[4] R. G. Bergman, Nature, 2007, 446, 391-393.

[5] K. Weissermel, H. J. Arpe, Industrial Organic Chemistry, 2nd ed, VCH Press, Weinheim, 1993.

[6] B. P. C. Hereijgers, B. M. Weckhuysen, J. Catal., 2010, 270, 16-25.

[7] R. Zhao, J. Dong, G. M. Lu, G. Qian, L. Yan, X. L. Wang, J. S. Suo, Chem. Commun., 2004, 904-905.

[8] L. X. Xu, C. H. He, M. Q. Zhu, K. J. Wu, Y. L. Lai, Catal. Commun., 2008, 9, 816-820.

[9] P. P. Wu, P. Bai, K. P. Loh, X. S. Zhao, Catal. Today, 2010, 158, 220-227.

[10] L. Li, C. Jin, X. C. Wang, W. J. Ji, Y. Pan, T. van der Knaap, R. van der Stoel, C. T. Au, Catal. Lett., 2009, 129, 303-311.

[11] Z. G. Sun, G. Li, L. P. Liu, H. O. Liu, Catal. Commun., 2012, 27, 200-205.

[12] J. Li, Y. Shi, L. Xu, G. Z. Lu, Ind. Eng. Chem. Res., 2010, 49, 5392-5399.

[13] R. Raja, G. Sankar, J. M. Thomas, J. Am. Chem. Soc., 1999, 121, 11926-11927.

[14] C. Chen, J. Xu, Q. H. Zhang, Y. F. Ma, L. P. Zhou, M. Wang, Chem. Commun., 2011, 47, 1336-1338.

[15] H. X. Yuan, Q. H. Xia, H. J. Zhan, X. H. Lu, K. X. Su, Appl. Catal. A, 2006, 304, 178-184.

[16] X. Guo, D. H. Shen, Y. Y. Li, M. Tian, Q. Liu, C. C. Guo, Z. G. Liu, J. Mol. Catal. A, 2011, 351, 174-178.

[17] G. Qian, D. Ji, G. M. Lu, R. Zhao, Y. X. Qi, J. G. Suo, J. Catal., 2005, 232,

\section{Graphical Abstract}

Chin. J. Catal., 2016, 37: 955-962 doi: 10.1016/S1872-2067(15)61067-1

\section{Ni-based catalysts derived from a metal-organic framework for selective oxidation of alkanes}

Ying Zhou, Jilan Long*, Yingwei Li *

South China University of Technology

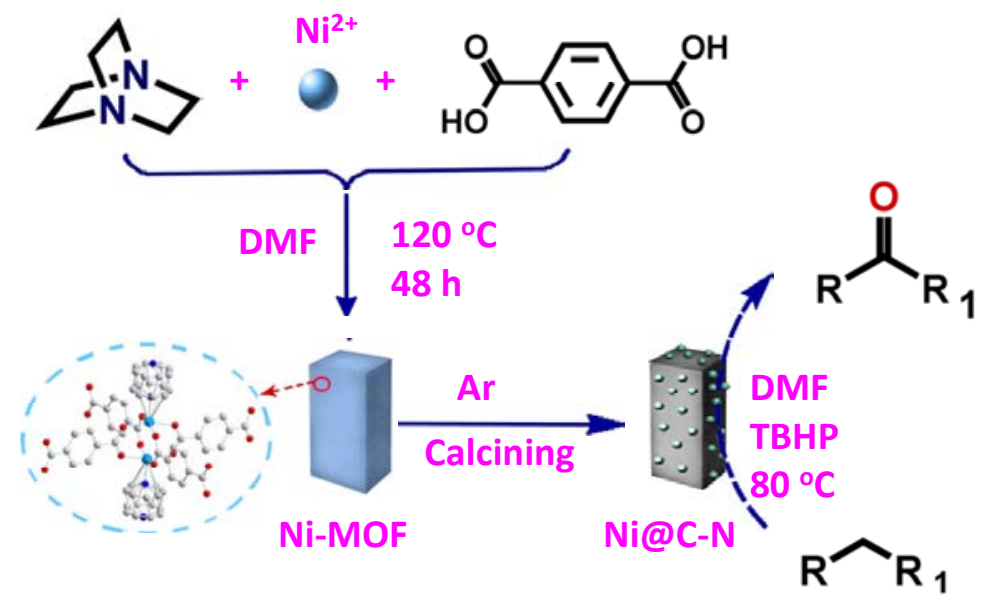

We developed a series of novel Ni-based catalysts by pyrolysis a Ni-containing metal-organic frameworks in an inert atmosphere at different temperatures. These Ni-based catalysts are highly active and selective in the oxidation of a variety of alkanes. 
378-386.

[18] X. X. Yang, H. Yu, F. Peng, H. J. Wang, ChemSusChem, 2012, 7, 1213-1217.

[19] J. L. Gu, Y. Huang, S. P. Elangovan, Y. S. Li, W. R. Zhao, I. Toshio, Y. Yamazaki, J. L. Shi, J. Phys. Chem. C, 2011, 115, 21211-21217.

[20] H. Zhao, J. C. Zhou, H. Luo, C. Y. Zeng, D. H. Li, Y. J. Liu, Catal. Lett., 2006, 108, 49-54.

[21] R. Zhao, Y. Q. Wang, Y. L. Guo, X. H. Liu, Z. G. Zhang, Y. S. Wang, W. C. Zhan, G. Z. Lu, Green Chem., 2006, 8, 459-466.

[22] J. L. Long, L. M. Wang, X. F. Gao, C. H. Bai, H. F. Jiang, Y. W. Li, Chem. Commun., 2012, 48, 12109-12111.

[23] J. L. Long, H. L. Liu, S. J. Wu, S. J. Liao, Y. W. Li, ACS Catal., 2013, 3, 647-654.

[24] H. Yu, F. Peng, J. Tan, X. W. Hu, H. J. Wang, J. Yang, W. X. Zheng, Angew. Chem. Int. Ed., 2011, 50, 3978-3982.

[25] X. H. Li, J. S. Chen, X. C. Wang, J. Sun, M. Antonietti, J. Am. Chem. Soc., 2011, 133, 8074-8077.

[26] H. H. Zhao, H. L. Song, L. L. Xu, L. J. Chou, Appl. Catal. A, 2013, 456, 188-196.

[27] F. Zhang, C. Chen, W. M. Xiao, L. Xu, N. Zhang, Catal. Commun., 2012, 26, 25-29.

[28] Y. F. Yang, L. T. Jia, B. Hou, D. B. Li, J. G. Wang, Y. H. Sun, J. Phys. Chem. C, 2014, 118, 268-277.

[29] W. X. Wang, Y. W. Li, R. J. Zhang, D. H. He, H. L. Liu, S. J. Liao, Catal. Commun., 2011, 12, 875-879.

[30] R. Q. Fang, H. L. Liu, R. Luque, Y. W. Li, Green Chem., 2015, 17, 4183-4188.

[31] K. Shen, L. Chen, J. L. Long, W. Zhong, Y. W. Li, ACS Catal., 2015, 5, 5264-5271.

[32] X. Qiu, X. Wang, Y.W. Li, Chem. Commun., 2015, 51, 3874-3877.

[33] W. Zhong, H. L. Liu, C. H. Bai, S. J. Liao, Y. W. Li. ACS Catal., 2015, 5, 1850-1858.

[34] X. Wang, W. Zhong, Y. W. Li, Catal. Sci. Technol., 2015, 5, 1014-1017.
[35] J. L. Long, Y. Zhou, Y. W. Li, Chem. Commun., 2015, 51, 2331-2134.

[36] C. Bai, X. Yao, Y. W. Li, ACS Catal., 2015, 5, 884-891.

[37] A. J. Amali, J-K. Sun, Q. Xu, Chem. Commun., 2014, 50, 1519-1522.

[38] W. Chaikittisilp, N. L. Torad, C. L. Li, M. Imura, N. Suzuki, S. Ishihara, K. Ariga, Y. Yamauchi, Chem. Eur. J., 2014, 20, 4217-4221.

[39] T. K. Kim, K. J. Lee, J. Y. Cheon, J. H. Lee, S. H. Joo, H. R. Moon, J. Am. Chem. Soc., 2013, 135, 8940-8946.

[40] H. L. Jiang, B. Liu, Y. Q. Lan, K. Kuratani, T. Akita, H. Shioyama, F. Q. Zong, Q. Xu, J. Am. Chem. Soc., 2011, 133, 11854-11857.

[41] G. Srinivas, V. Krungleviciute, Z. X. Guo, T. Yildirim, Energy Environ. Sci., 2014, 7, 335-342.

[42] J. Y. Lee, D. H. Olson, L. Pan, T. J. Emge, J. Li, Adv. Funct. Mater., 2007, 17,1255-1262.

[43] J. L. Long, B. Yin, Y. W. Li, B. L. Zhang, AIChE J., 2014, 60, 3565-3576.

[44] Y. X. Yang, C. Ochoa-Hernández, P. Pizarro, V. A. de la P O’Shea, J. M. Coronado, D P. Serrano, Fuel, 2015, 144, 60-70.

[45] M. C. Biesingera, B. P. Payne, A. P. Grosvenor, L. W. M. Lau, A. R. Gerson, R. S. C. Smart, Appl. Surf. Sci, 2011, 257, 2717-2730.

[46] F. Severino, J. L. Brito, J. Laine, J. L. G Fierro, A. L. Agudo, J. Catal., 1998, 177, 82-95.

[47] P. Liu, E. J. M. Hensen, J. Am. Chem. Soc., 2013, 135, 14032-14035.

[48] J. M. L. Martínez, E. Rodríguez-Castellón, R. M. T. Sánchez, L. R. Denaday, G. Y. Buldain, V. C. Dall' Orto, J. Mol. Catal. A, 2011, 339, 43-51.

[49] F. G. Souza, P. Richa, A. de Siervo, G. E. Oliveira, C. H. M. Rodrigues, M. Nele, J. C. Pinto, Macromol. Mater. Eng., 2008, 293, 675-683.

[50] J. S. Stevens, S. J. Byard, C. A. Muryn, S. L. M. Schroeder, J. Phys. Chem. B, 2010, 114, 13961-13969.

[51] M. Shibata, Y. Kimura, D. Yaginuma, Polymer, 2004, 45, 7571-7577.

[52] X. L. Li, H. L. Wang, J. T. Robinson, H. Sanchez, G. Diankov, H. J. Dai, J. Am. Chem. Soc., 2009, 131, 15939-15944.

\title{
金属有机骨架衍生 Ni 基材料催化烷烃选择氧化
}

\author{
周颖, 隆继兰 ${ }^{*}$, 李映伟
}

华南理工大学化学与化工学院, 制浆造纸工程国家重点实验室广东广州 510640

摘要: $\mathrm{N}$ 掺杂碳基纳米材料由于具有高稳定性、良好的导电性、较大的孔体积和比表面积等特点而受到了国内外广泛的关 注, 在气体吸附、催化、电化学以及燃料电池等许多领域表现出潜在应用价值. $\mathrm{N}$ 掺杂碳材料的制备主要采用两种方法, 即 后合成法和原位合成法. 后合成法是指采用含 $\mathrm{N}$ 化合物 (如尿素等) 对已合成的碳材料进行处理, 但所制材料中 $\mathrm{N}$ 含量往 往偏低, 且 $\mathrm{N}$ 活性位不够稳定. 要得到 $\mathrm{N}$ 含量较高且稳定的 $\mathrm{N}$ 掺杂碳材料常常采用原位合成法, 即以富氮前体作为模板, 在热解过程中 $\mathrm{N}$ 原位嵌入碳纳米材料中, 因而具有结构稳定, $\mathrm{N}$ 含量丰富等优点.

金属有机骨架 (MOFs) 材料是一种新型的类沸石类多孔材料, 是由金属离子和有机配体通过配位键键合而成的拓扑结 构. 该类材料具有较高的孔隙率和比表面积以及结构可调控性等特点. 通过调节金属中心和配体种类, 引入含 $\mathrm{N}$ 配体, 可 以得到不同类型的含 $\mathrm{N}$ 的 MOFs. 此外, 含 $\mathrm{N}$ 的 MOFs 在一定温度下热解能有效减少 $\mathrm{N}$ 元素的流失, 因此, MOFs 是一类 优秀的用于制备 $\mathrm{N}$ 掺杂碳基纳米材料的模板材料. 近年来, 以含 $\mathrm{N}$ 的金属有机骨架材料为模板, 通过简单热解一步合成 $\mathrm{N}$ 掺杂碳基纳米催化剂, 已成为国内外研究的热点之一.

本文在惰性气氛中采用直接热解 $\mathrm{Ni}$ 基 MOF 方法制备了 $\mathrm{N}$ 掺杂 $\mathrm{C}$ 包裹的 $\mathrm{Ni}$ 纳米颗粒, 并利用 $\mathrm{X}$ 射线粉末衍射 (PXRD)、 $\mathrm{N}_{2}$ 吸附脱附、扫描电子显微镜 (SEM)、透射电子显微镜 (TEM)、原子吸收光谱 (AAS)、X 射线光电子能谱 (XPS) 等对该复合材料的组成和结构进行了表征.

PXRD 测试结果表明, 经过热解, 催化剂中出现了大量的金属 $\mathrm{Ni}$ 粒子, 说明 $\mathrm{Ni}-\mathrm{MOF}$ 中的 $\mathrm{Ni}^{2+}$ 离子在热解过程中被原 位还原成了 $\mathrm{Ni}$ 纳米颗粒. $\mathrm{N}_{2}$ 吸附脱附结果表明, 热解前的 Ni-MOF 结构中只存在微孔结构, 但是热解 Ni@C-N 材料中生 成了大量的介孔或大孔结构, 从而有利于反应底物与催化剂活性位点的接触. SEM 结果表明, 在较低的温度下热解, 催化 
剂可以保持 MOFs 原来的构型, 且结构疏松多孔; 而在较高的温度下热解, 如 $800{ }^{\circ} \mathrm{C}$, 将有大量的碳纳米管生成. TEM 结 果表明, 随着热解温度升高, 催化剂中 $\mathrm{Ni}$ 纳米颗粒逐渐增大. 从 HRTEM 测试结果可以清晰看出, 高温热解时有石墨烯结 构生成, 并且生成的 $\mathrm{Ni}$ 纳米颗粒原位嵌入了石墨烯结构中, 因而有利于 $\mathrm{Ni}$ 纳米颗粒的分散, 从而提高催化剂的活性. XPS 结果进一步证明, 热解过程中, $\mathrm{Ni}^{2+}$ 被原位还原成了零价的 $\mathrm{Ni}$ 纳米粒子, 此外, $\mathrm{N} 1 \mathrm{~s}$ 谱图也进一步证明 $\mathrm{N}$ 在热解过程中原 位嵌入了生成的石墨烯结构中.

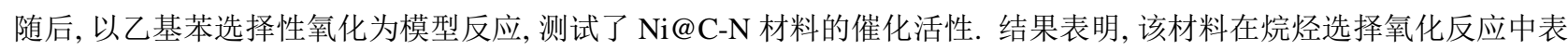
现出很高的催化活性和选择性, 尤其是 Ni@C-N-900-8h, 在温和的反应条件下, 可有效催化一系列饱和烷烃的选择氧化, 获 得很高的氧化产物收率, 且重复利用多次后其活性和选择性没有明显的下降.

关键词: 镍; 纳米粒子; 金属有机骨架; 烷烃; 氧化; 多相催化

收稿日期: 2016-01-27. 接受日期: 2016-02-25. 出版日期: 2016-06-05.

*通讯联系人. 电话: 15182908656; 电子信箱: xlong612@126.com

\#通讯联系人. 电话: 020-87113656; 电子信箱: liyw@scut.edu.cn

基金来源：国家自然科学基金(21322606, 21436005, 21576095); 制浆造纸工程国家重点实验室开放基金(2015TS03); 高等学校博 士学科点专项科研基金(20120172110012); 中央高校基本科研业务费(2015ZP002，2015PT004); 广东省自然科学基金 (2013B090500027).

本文的英文电子版由Elsevier出版社在ScienceDirect上出版(http://www.sciencedirect.com/science/journal/18722067).

\section{Chinese Journal of Catalysis (《催化学报》)文种变更为英文的通知}

经国家新闻出版广电总局批准，《催化学报》于 2016 年开始业务范围中的文种变更为英文, 变更后的期刊 基本信息如下：期刊名称Chinese Journal of Catalysis (《催化学报》), 中国标准连续出版物号 ISSN 0253-9837, 国内统一连续出版物号 CN 21-1601/O6, 月刊.

今后, 本刊录用稿件全部以英文全文形式发表, 英文全文电子版在 Elsevier 出版社 ScienceDirect 网络平台 上出版. 为兼顾国内读者并保持期刊的中国特色，《催化学报》印刷版将同时刊登英文文章的扩展版中文摘要.

我们相信, 期刊文种变更为英文后将为国内外催化研究工作者提供一个更好的交流和展示平台. 《催化学 报》编委会及编辑部全体成员将通过不解努力将该刊推向一个新的高度, 使其以更好的质量、更高的学术水平 面向世界, 跻身于国际优秀学术期刊行列. 